\title{
Subsurface dinoflagellate populations, frontal blooms and the formation of red tide in the southern Benguela upwelling system
}

\author{
G. C. Pitcher*, A. J. Boyd, D. A. Horstman, B. A. Mitchell-Innes \\ Sea Fisheries Research Institute, Private Bag X2, Rogge Bay 8012, Cape Town, South Africa
}

\begin{abstract}
The West Coast of South Africa is often subjected to problems associated with red tides which are usually attributed to blooms of migratory dinoflagellates. This study investigates the coupling between the physical environment and the biological behaviour and physiological adaptation of dinoflagellates in an attempt to understand bloom development, maintenance and decine. Widespread and persistent subsurface dinoflagellate populations dominate the stratified waters of the southern Benguela during the latter part of the upwelling season. Chlorophyll concentrations as high as $50 \mathrm{mg}$ $\mathrm{m}^{-3}$ are associated with the thermocline at approximately $20 \mathrm{~m}$ depth but photosynthesis in this region is restricted by low light. The subsurface population is brought to the surface in the region of the upwelling front. Here increased light levels are responsible for enhanced production, in some instances exceeding $80 \mathrm{mgC} \mathrm{m}^{-3} \mathrm{~h}^{1}$, and resulting in dense dinoflagellate concentrations in and around the uplifted thermocline. Under particular wind and current conditions these frontal blooms are transported and accumulated inshore and red tides are formed.
\end{abstract}

KEY WORDS: Dinoflagellates Subsurface populations - Frontal blooms Red tide - Upwelling systems

\section{INTRODUCTION}

The South African coast, particularly the West Coast, is subjected to several problems associated with blooms of harmful and toxic algae. These harmful algal blooms are usually characterized by the proliferation and occasional dominance of a particular species of toxic or otherwise harmful alga, and in many instances these proliferations discolour the water, a phenomenon known as red tide. These blooms are able to impact both commercial and recreational interests in the coastal region. Mass faunal mortalities resulting from algal toxins (Horstman 1981, Horstman et al. 1991), and human illness from contaminated shellfish (Grindley \& Sapeika 1969, Popkiss et al. 1979, Horstman 1981, Horstman et al. 1991, Pitcher et al. 1993b, Pitcher \& Matthews 1996) are common events, and blooms may also cause harm resulting either from the indirect effects of biomass accumulation, such as anoxia (Grindley \& Taylor 1964, Horstman 1981, Matthews \&

\footnotetext{
•E-mail: gpitcher@sfri2.wcape.gov.za
}

Pitcher 1996), or from physical damage, such as the clogging of fish gills (Grindley \& Nel 1968, Brown et al. 1979).

The Benguela is one of the 4 major eastern boundary current regions of the World ocean and wind-driven upwelling is a feature of ocean circulation along the entire western coast of southern Africa (Shannon 1985). Here harmful algal blooms are usually attributed to migratory dinoflagellates or other flagellate species and red tides represent spectacular localized accumulations of widespread seasonal dinoflagellate blooms (Pitcher et al. 1993a). The formation of red tide is closely related to the prevailing winds of the southern Benguela which govern most hydrodynamic processes on the continental shelf. As a consequence Pitcher et al. (1995) have identified several meteorological patterns and cycles associated with the development of red tide at the seasonal, event and interannual scales. The incidence of red tide is highest during the latter part of the upwelling season during transitions in the synoptic weather patterns which result in diminished upwelling activity and increased thermal stratification (Pitcher et al. 1993a). Investigation of 
across-shelf and alongshore phytoplankton distributions has located surface dinoflagellate accumulations in the region of upwelling fronts (Pitcher \& Boyd 1996). Following relaxation of upwelling, across-shelf currents become weak and directed onshore, in which case these dinoflagellate blooms are accumulated inshore, where poleward surface flow has been implicated in the southward propagation of red tide (Pitcher \& Boyd 1996).

This study further investigates the relationship between wind patterns, the hydrography and the formation of red tide on the South African West Coast, in an area subjected to a narrow band of upwelling resulting directly from Ekman pumping (Nelson \& Hutchings 1983). The coupling between the physical environment and the biological behaviour and physiological adaptation of dinoflagellate populations is investigated over a broad range of temporal and spatial scales. Many of the findings of this study, relating to the relative importance of biological and physical processes and their interactions in controlling bloom dynamics, are presumably applicable to other upwelling-driven systems. This information will contribute to the ultimate goal of determining the principal causes of red tide, in order to achieve better skill at forecasting their occurrence and predicting the consequences for phytoplankton of environmental changes in coastal waters.

\section{METHODS}

Most of the work on which this paper reports was conducted off Lambert's Bay, South Africa, and comprised the periodic sampling of a 28 nautical mile ( $n$ mile) transect, daily monitoring at an inshore station and an intensive $24 \mathrm{~h}$ sampling of red tide (Fig. 1). A study transecting the Coastal Transition Zone Front provided observations from further offshore (Fig. 1).

The sets of data presented are summarized as follows:

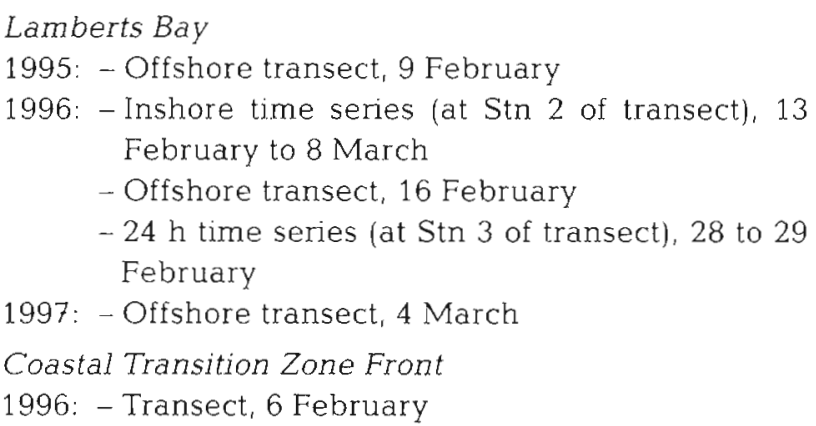

Wind velocity was recorded from a meteorological station situated in the Cape Columbine region. The daily inshore monitoring at Lambert's Bay was con-

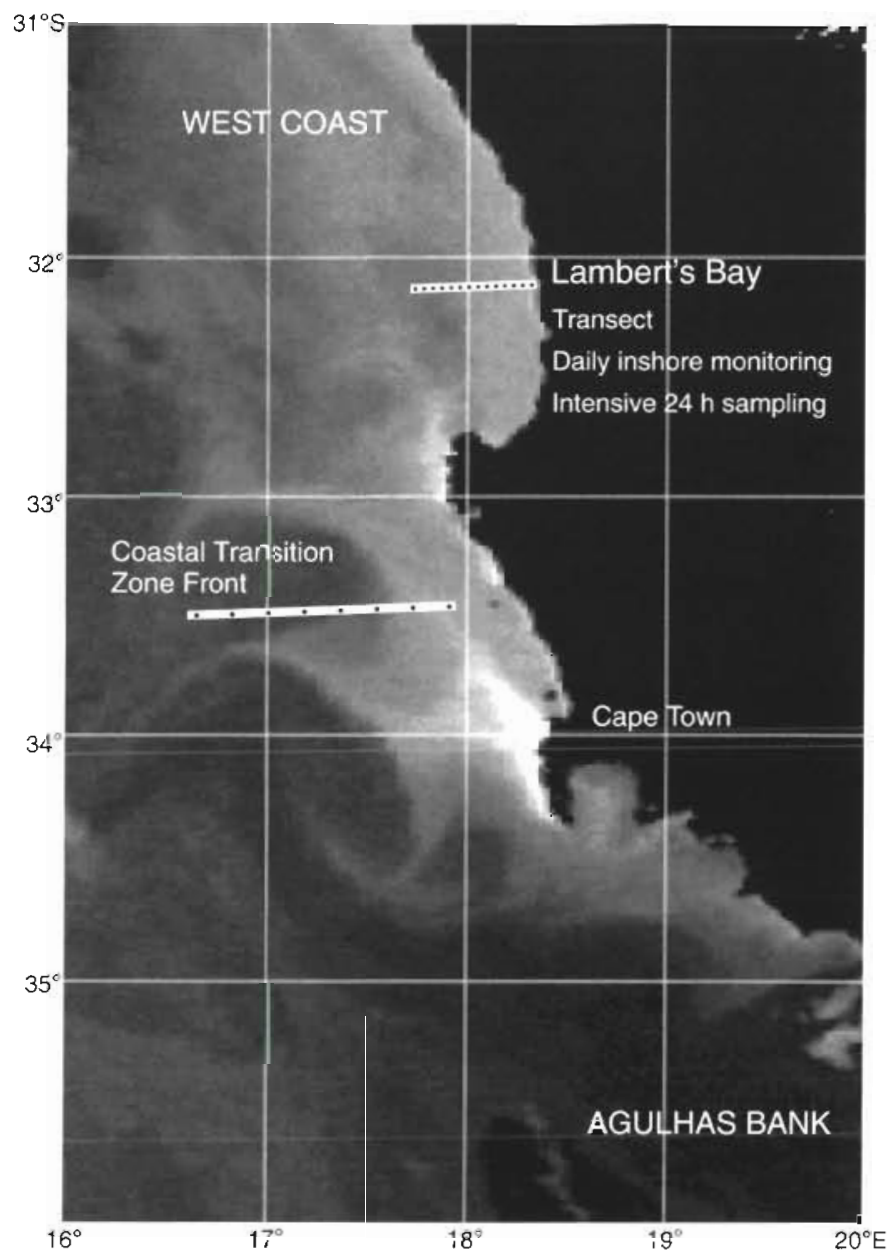

Fig. 1. Satellite thermal image of area of study on 6 February 1996. Off Lambert's Bay, South Africa, an inshore station was sampled daily for the period 13 February to 8 March 1996. A 28 mile transect of 14 stations was sampled intermittently and a single intensive $24 \mathrm{~h}$ sampling of red tide was also undertaken during this period off Lambert's Bay. Eight stations transecting the Coastal Transition Zone Front were sampled on 6 February 1996

ducted at Stn 2 of the transect line in $12 \mathrm{~m}$ of water. Profiling of the water column for temperature and in situ chlorophyll fluorescence was conducted by means of a Chelsea Instruments Aquapack. A Profiling Natural Fluorometer (PNF-300, Biospherical Instruments Inc.) was used to profile natural or solar-induced fluorescence in order to provide a measure of the rate of photosynthesis (Chamberlin et al. 1990). These measurements compared favourably with productivity estimates obtained during this study by means of the standard ${ }^{14} \mathrm{C}$ technique (Mitchell-Innes \& Pitcher unpubl.). Samples for nitrate, chlorophyll $a$ and phytoplankton analysis were collected from $0,2,4$ and $7 \mathrm{~m}$. The transect studies off Lambert's Bay usually comprised 14 stations at $2 \mathrm{n}$ mile intervals and profiling by means of the Aquapack was conducted at each station. PNF pro- 
files were performed at Stns 2, 5, 8, 11 and 14. Here samples for nitrate, chlorophyll $a$ and phytoplankton analysis were collected from 0, 5, 10 and $20 \mathrm{~m}$. A $300 \mathrm{kHz}$ Acoustic Doppler Current Profiler (ADCP) was used to measure earth-referenced currents between 5 and $100 \mathrm{~m}$ depth along the March 1997 transect. The Coastal Transition Zone Front transect comprised 8 stations at $10 \mathrm{n}$ mile intervals. Temperature and fluorescence profiles were obtained using a thermistor and Chelsea Instruments Aquatracka attached to a rosette water sampler. Samples for the analysis of phytoplankton were collected from the fluorescence maximum.

Samples for the analysis of nitrate were frozen and later analysed according to the methods of Mostert (1983).

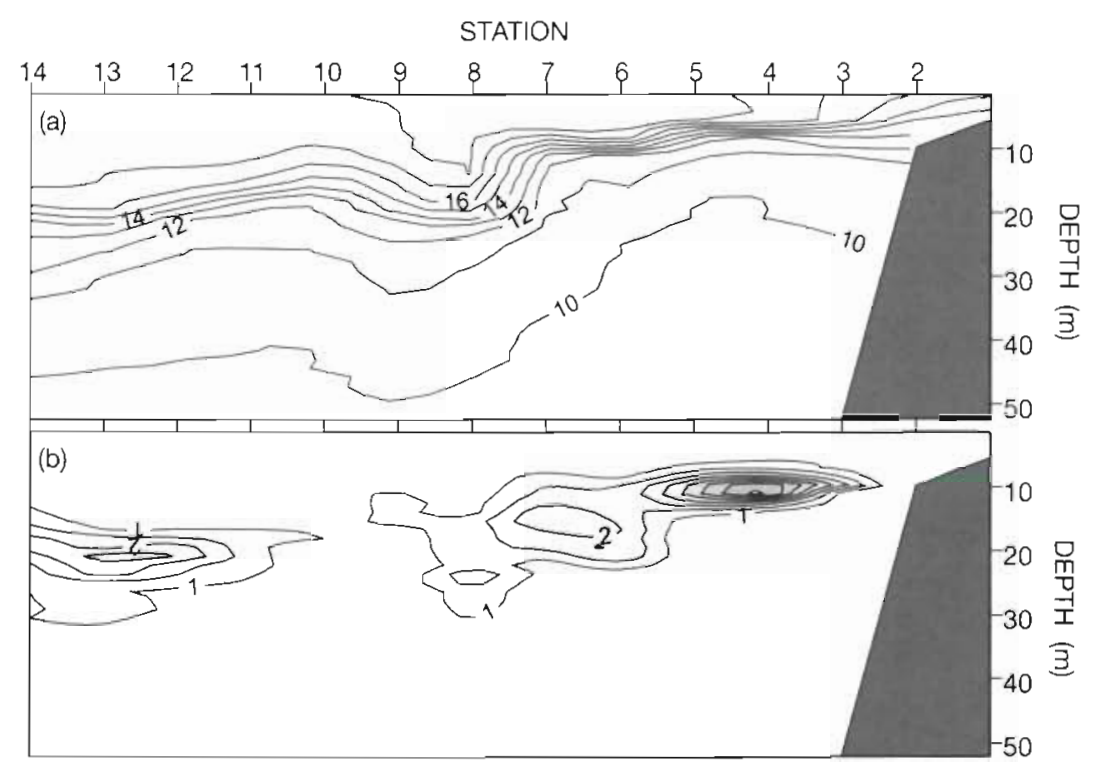

Fig. 2. A 28 n mile transect off Lambert's Bay conducted on 9 February 1995 of (a) temperature $\left({ }^{\circ} \mathrm{C}\right.$ ) and (b) in situ fluorescence
Chlorophyll a samples were analysed by fluorometric analysis as detailed by Parsons et al. (1984) and in some instances extracted chlorophyll a was used to calibrate in situ fluorescence profiles. Samples for phytoplankton analysis were fixed in buffered formalin and enumerated by the Utermohl method (Hasle 1978). Estimates of phytoplankton carbon were made indirectly from cell counts and cell volumes (Smayda 1978) in order to assess the contribution of taxonomic groups such as the diatoms and dinoflagellates to the total phytoplankton biomass.

\section{RESULTS}

\section{Lambert's Bay 1995}

\section{Offshore transect}

A 28 n mile transect comprising 14 stations off Lambert's Bay on 9 February 1995 revealed a highly stratified environment and a subsurface in situ fluorescence maximum associated with the base of the thermocline (Fig. 2). Offshore the thermocline was observed at $20 \mathrm{~m}$ depth, but as the water depth decreased shoreward there was a shallowing of the thermocline to a depth of $10 \mathrm{~m}$ and a corresponding intensification of the fluorescence maximum. Turbulent entrainment in the bottom boundary layer through tidal currents is seemingly responsible for the shallowing of the thermocline and the doming of the isotherms inshore of Stn 8 which corresponds to a steepening of the bottom topography in this region (G. Nelson, Sea Fisheries Research Institute, pers. comm.). Offshore the thermocline separated water of $>16^{\circ} \mathrm{C}$ from water of $<12^{\circ} \mathrm{C}$ and also demarcated a pronounced nitrate gradient of typically $<2 \mu \mathrm{M}$ in the surface layer to $>20 \mu \mathrm{M}$ in the bottom layer. The upward curving of isotherms inshore distinguished a zone of weak upwelling. Although the horizontal temperature gradient between the cooler inshore and stratified offshore waters was relatively weak, enhanced in situ fluorescence at Stn 4 coincided with this zone of transition and a cross-frontal surface nitrate gradient of $>5 \mu \mathrm{M}$ was measured.

Phytoplankton concentrations in the surface waters, especially those offshore, were very low. The subsurface phytoplankton assemblage was dominated by dinoflagellates with the toxic species Dinophysis acuminata and $D$. fortii particularly prominent. There was a tendency for these Dinophysis species to be associated with a heterotrophic community which included the species Peridinium steinii. Photosynthetic dinoflagellates were more common inshore and the species Ceratium lineatum, Prorocentrum micans and Scripsiella trochoideum dominated at Stn 4.

\section{Lambert's Bay 1996}

\section{Inshore time series}

The importance of local wind events in governing the observed hydrography and the biological response of the inshore environment was clearly evident from the time series of wind, temperature and in situ fluorescence for the period 13 February to 8 March 1996 (Fig. 3). Sea temperatures were sensitive to changes in the wind, exhibiting an almost immediate response Winds with a strong southerly component caused 

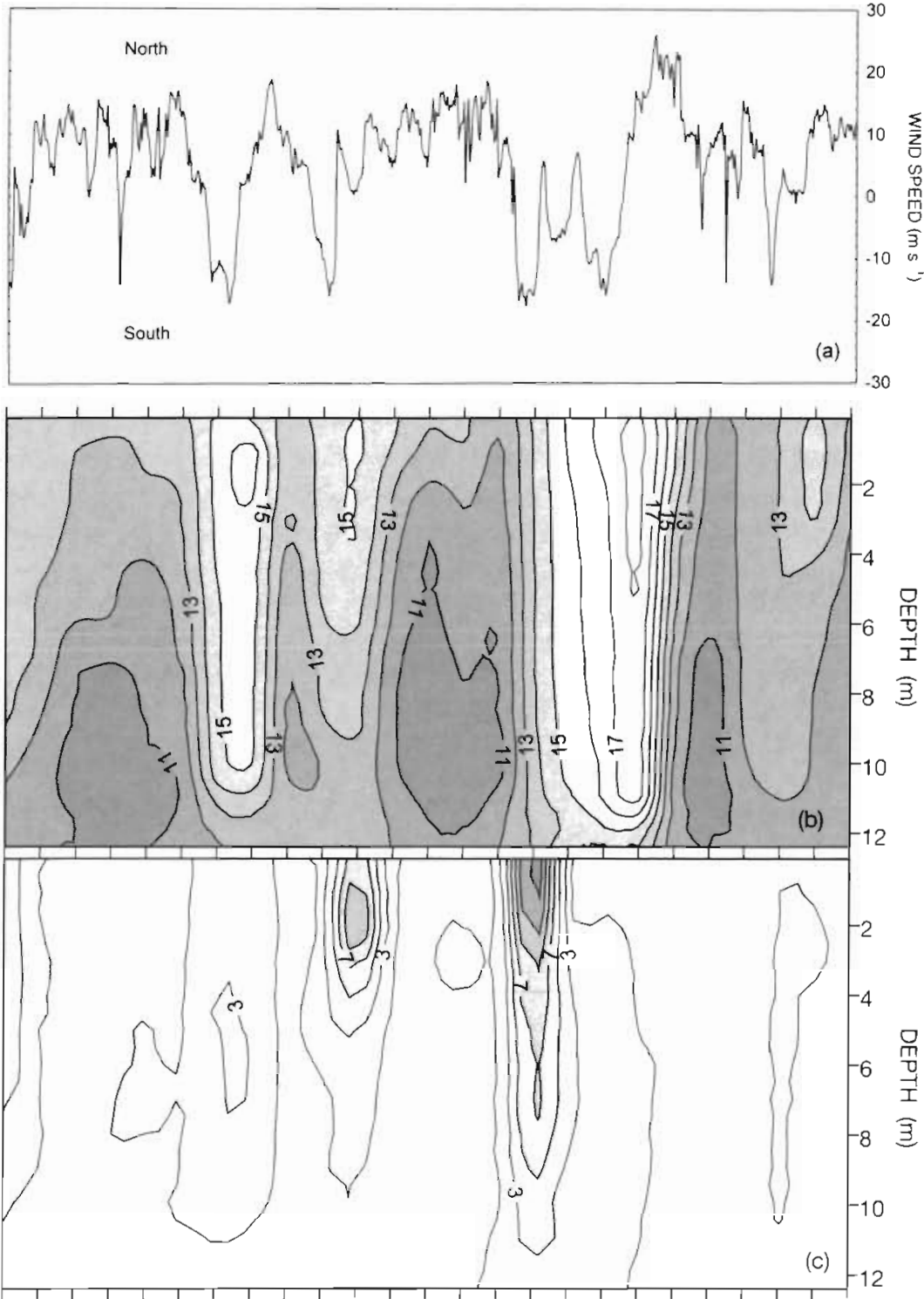

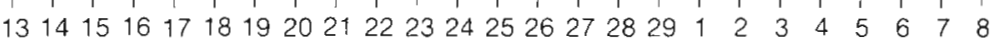
DATE

Fig. 3. Time senes of (a) wind, (b) temperature $\left({ }^{\circ} \mathrm{C}\right)$ and $(\mathrm{c})$ in situ fluorescence at an inshore station off Lambert's Bay for the period 13 February to 8 March

water temperatures to decrease as a consequence of upwelling whereas wind reversals caused a rise in sea temperature. The entire time series was characterized by 3 prominent wind reversals (18 to 19 February; 22 February; 28 February to 1 March), each of which was associated with a notable increase in temperature and in situ fluorescence.

Scrutiny of the period 25 February to 4 March 1996 revealed the importance of advective processes dictated by meteorological forcing in controlling rapid shifts in the biomass and species composition of the inshore phytoplankton community (Fig. 4). The development of red tide on 28 February in association with the onshore movement of the upwelling front is clearly demonstrated by this inshore time series. Following persistent upwelling favourable winds, a Thalassiosira-dominated diatom community was conspicuous in the cold water present on 25 February. Phytoplankton biomass and the contribution of dinoflagellates to the phytoplankton community increased following relaxation of the upwelling winds and the introduction of warmer water. The dinoflagellate population was more diverse than the diatom community and included the species Alexandrium catenella, Ceratium furca, Dinophysis acuminata, Prorocentrum micans and Scripsiella trochoideum. The landward retreat of the upwelling front on 28 February concentrated the dinoflagellate bloom inshore and red tide was formed. It was interesting to observe that this bloom, dominated by $C$. furca, remained associated with water of a narrow temperature range of 12 to $15^{\circ} \mathrm{C}$ and that the red tide was displaced with the introduction of still warmer water. A shift in the dinoflagellate assemblage towards a heterotrophic community was observed in water $>15^{\circ} \mathrm{C}$ with Peridinium steinii dominating the population. It was also during this period that $D$. acuminata formed a prominent component of the phytoplankton. The introduction of cooler water on 3 to 4 March with the resumption of upwelling favourable winds was allied to the return of a diatom-dominated community.

A transect conducted on 25 February indicated that the upwelling front and associated dinoflagellate bloom were located $6 \mathrm{n}$ miles offshore, indicating that the front moved shoreward at a rate of at least $2 \mathrm{n}$ miles $\mathrm{d}^{-1}$, which equates to a minimal current speed of $5 \mathrm{~cm}$ $\mathrm{s}^{-1}$ in the upper layer.

\section{Offshore transect}

Sampling of the $28 \mathrm{n}$ mile transect off Lambert's Bay on 16 February 1996 provided insight into the spatial distribution of the phytoplankton populations observed at the inshore monitoring station (Fig. 5). Sampling followed several days of moderate upwelling 


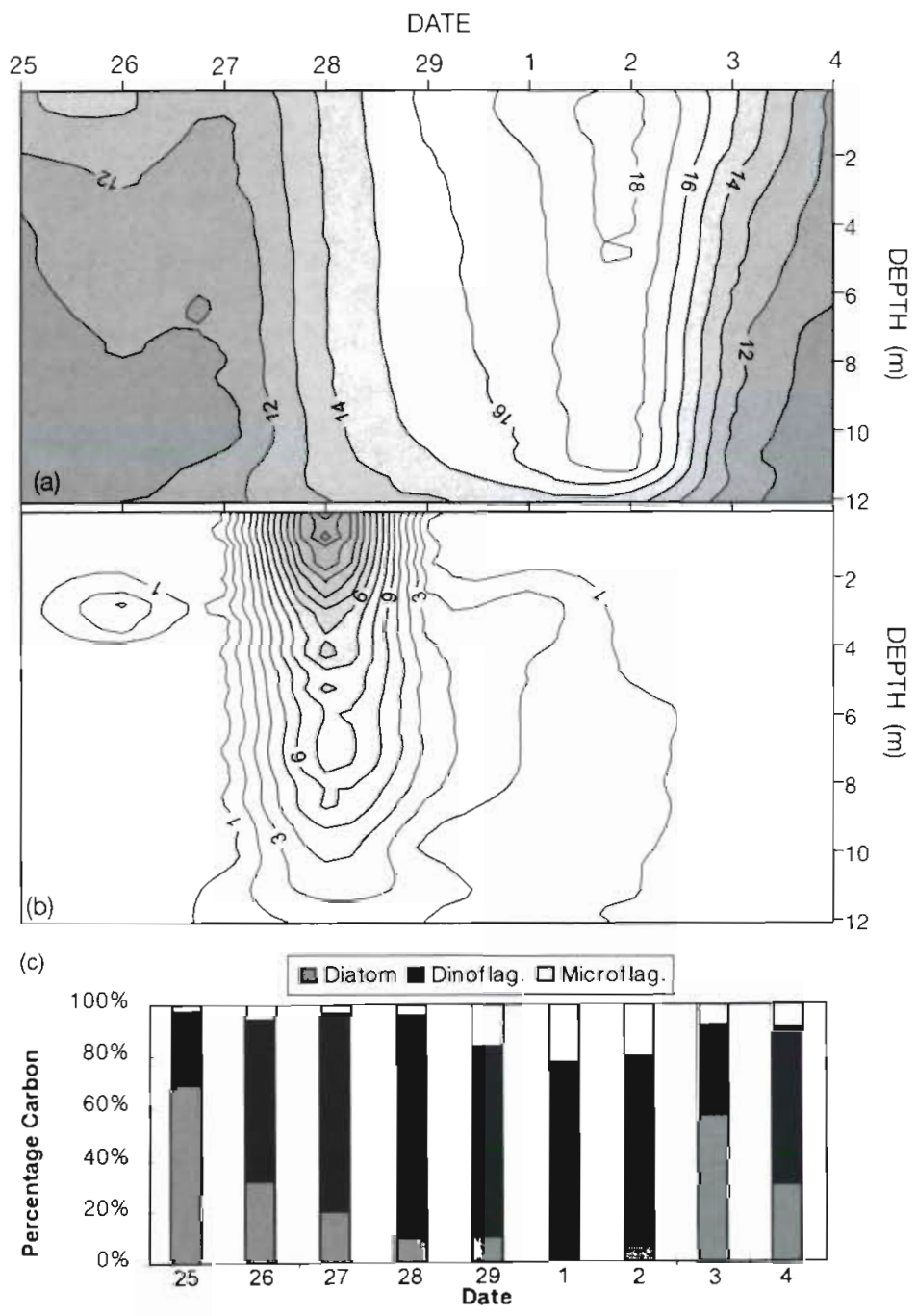

Fig. 4. Time series of (a) temperature $\left({ }^{\circ} \mathrm{C}\right.$ ) (b) in situ fluorescence and (c) species composition (expressed as \% carbon) for the period $25 \mathrm{Feb}$ ruary to 4 March 1996 winds. The thermal structure revealed a progression from well-mixed water of $<12{ }^{\circ} \mathrm{C}$ inshore to a highly stratified water column further offshore. Here a strong thermocline at approximately $20 \mathrm{~m}$ depth separated warm nutrientdepleted surface water of $>15^{\circ} \mathrm{C}$ and $<2 \mu \mathrm{M}$ nitrate from cold nutrient-rich bottom water of $<11^{\circ} \mathrm{C}$ and $>20 \mu \mathrm{M}$ nitrate. As a result of recent upwelling, the horizontal gradients across the frontal boundary were relatively strong

Fig. 5. A 28 n mile transect off Lambert's Bay on 16 February 1996 of (a) temperature $\left({ }^{\circ} \mathrm{C}\right)$ and (b) in situ fluorescence with a cross-frontal surface gradient of $>15 \mu \mathrm{M}$ nitrate. In situ fluorescence values were highest in the frontal region where stratified and mixed waters met. The subsurface fluorescence maximum offshore was again a feature associated with the thermocline.

A Nitzschia-dominated diatom community was present in the cooler, well-mixed waters inshore of the upwelling front. The Ceratium furca-dominated dinoflagellate population was observed further offshore and exhibited a consistent disposition to the gradients of temperature and nutrients. In the region of the upwelling front the population appeared as a high biomass surface bloom but offshore the population was confined to a narrow subsurface layer in the vicinity of the thermocline. Vertical profiles of light, biomass, production and productivity per unit chlorophyll $\left(P^{\mathrm{B}}\right)$ provided further insight into the physiology and vertical positioning of this population with reference to the physical environment (Fig. 6). Surface incident radiation along the transect approximated $2500 \mu \mathrm{mol} \mathrm{m} \mathrm{m}^{-2} \mathrm{~s}^{-1}$. $P^{\mathrm{B}}$ values tended to be highest at the surface, exceeding $4 \mathrm{mgC} \mathrm{mgchl}^{-1} \mathrm{~h}^{-1}$. At Stn 2, where phytoplankton biomass was relatively low and light attenuation less dramatic, assimilation indices were marginally higher. The highest rates of production were observed in the frontal region at $\operatorname{Stn} 5$ and generally exceeded $80 \mathrm{mgC} \mathrm{m}^{-3}$ $\mathrm{h}^{-1}$ in the upper $5 \mathrm{~m}$. Despite chlorophyll concentrations of $>30 \mathrm{mg} \mathrm{m}^{-3}$ below $10 \mathrm{~m}$ depth, shading and a reduction of irradiance to $<5 \mu \mathrm{mol} \mathrm{m} \mathrm{m}^{-2} \mathrm{~s}^{-1}$ accounted for the fact that

\section{STATION}

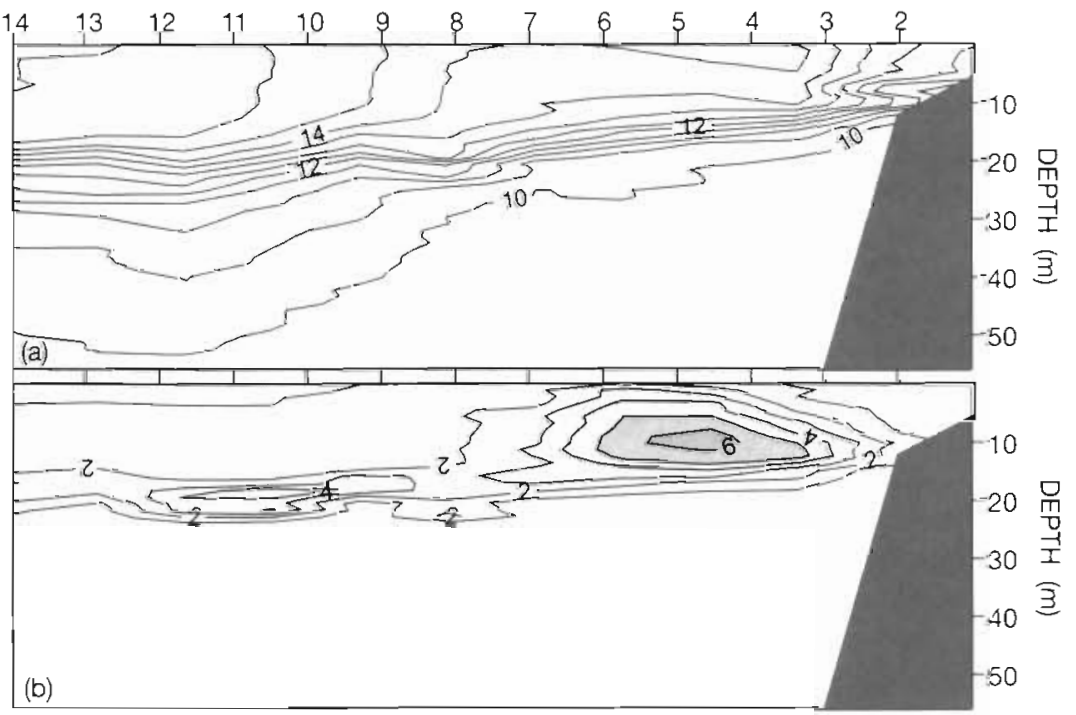



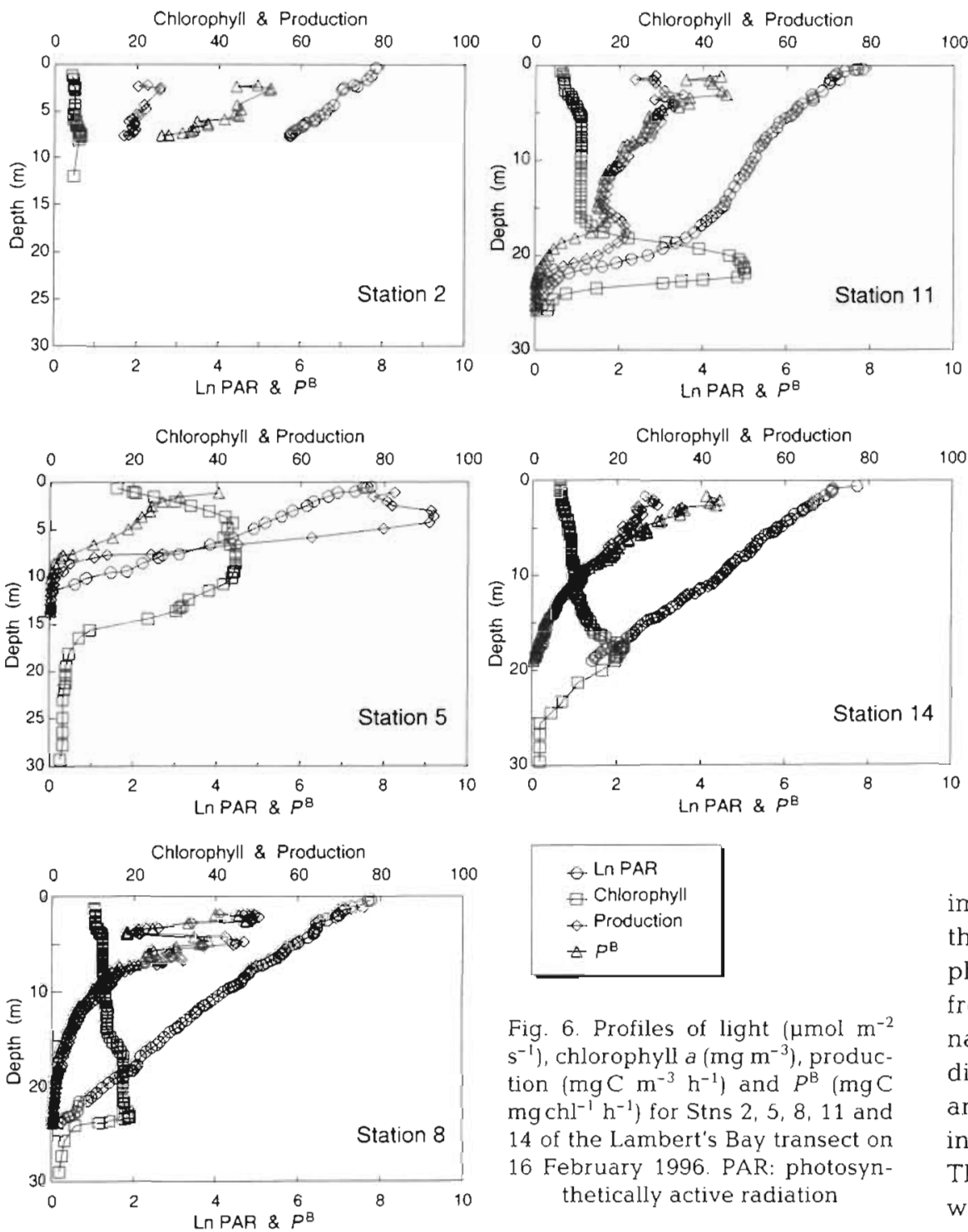

100

$\sigma \operatorname{Ln} P A R$

$\exists$ Chlorophyll

. Production

$\Delta \mathrm{P}^{\mathrm{B}}$

Fig. 6. Profiles of light $\left(\mu \mathrm{mol} \mathrm{m}^{-2}\right.$ $\left.\mathrm{s}^{-1}\right)$, chlorophyll a ( $\mathrm{mg} \mathrm{m}^{-3}$ ), production $\left(\mathrm{mgC} \mathrm{m}^{-3} \mathrm{~h}^{-1}\right)$ and $p^{\mathrm{B}}(\mathrm{mgC}$ $\mathrm{mg} \mathrm{chl}^{-1} \mathrm{~h}^{-1}$ ) for Stns $2,5,8,11$ and 14 of the Lambert's Bay transect on 16 February 1996. PAR: photosynthetically active radiation

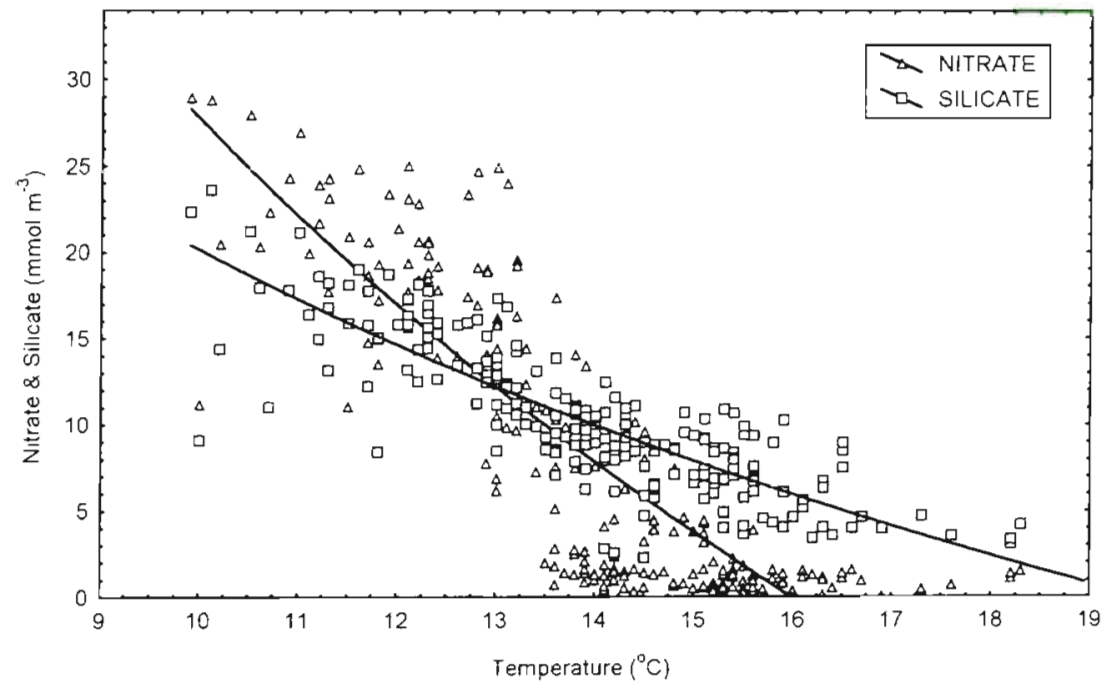

most of the production was confined to the upper $8 \mathrm{~m}$. Surface production was reduced offshore of the front, as surface chlorophyll concentrations declined to $<10 \mathrm{mg} \mathrm{m}^{-3}$. Despite the development of a pronounced subsurface chlorophyll maximum offshore, production maxima at each station nevertheless remained near-surface. Chlorophyll concentrations as high as $50 \mathrm{mg} \mathrm{m}^{-3}$ were observed at the subsurface maximum situated at approximately $20 \mathrm{~m}$ depth. Production in this region, however, did not exceed $3 \mathrm{mgC} \mathrm{m}^{-3} \mathrm{~h}^{-1}$ in a light environment of $<3 \mu \mathrm{mol} \mathrm{m}^{-2} \mathrm{~s}^{-1}$. These light levels corresponded to $<0.5 \%$ of the surface irradiance and $P^{\mathrm{B}}$ values of $<0.2 \mathrm{mgC} \mathrm{mg} \mathrm{chl}^{-1} \mathrm{~h}^{-1}$ indicated very low growth in the region of the thermocline.

Nutrient ratios have often been implicated as important in controlling the relative abundance of various phytoplankton groups. The switch from diatom to dinoflagellate dominance in this study is reflected by the different rates of decline of nitrate and silicate concentrations with an increase in sea temperature (Fig. 7) The dominance of dinoflagellates in warmer waters results in the more rapid depletion of nitrate relative to silicate in water $>13^{\circ} \mathrm{C}$.

\section{$24 \mathrm{~h}$ time series}

At midday on 28 February 1996 intensive sampling of the dinoflagellate bloom was initiated for a $24 \mathrm{~h}$ period (Fig. 8). The thermal structure indicated conditions of downwelling

Fig. 7. Nitrate and silicate concentrations as a function of temperature. Data were best fit by the following regression equations for nitrate $(y=163.413$ 1.35.722 $\left.\log x, r^{2}=0.72\right)$ and silicate $(y=$ $89.464-69.341 \log x_{1} r^{2}=0.71$ ) 
typically associated with the shoreward accumulation of the bloom. Ceratium furca dominated the bloom, but Prorocentrum micans was also abundant, together

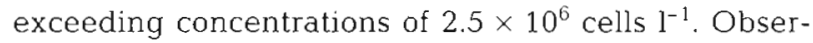
vations during this period revealed pronounced diel vertical migration, the population descending during the night into nutrient-rich bottom water. The motility of the population thus allowed the exploitation of nutrients over a relatively large part of the water column. In situ fluorescence indicated that the population began its descent from the surface in the late afternoon and attained a maximum depth of 12 to $14 \mathrm{~m}$ at 02:00 h. Ascent of the population occurred rapidly over an approximately $4 \mathrm{~h}$ period with surface accumulations again evident by 08:00 h. During the day in situ fluorescence at the surface declined and fluorescence maxima were established at a depth of $2 \mathrm{~m}$. This observed reduction of in situ fluorescence at the nearsurface could alternatively be a function of inhibition of chlorophyll fluorescence by bright light (Cullen \& Lewis 1995).

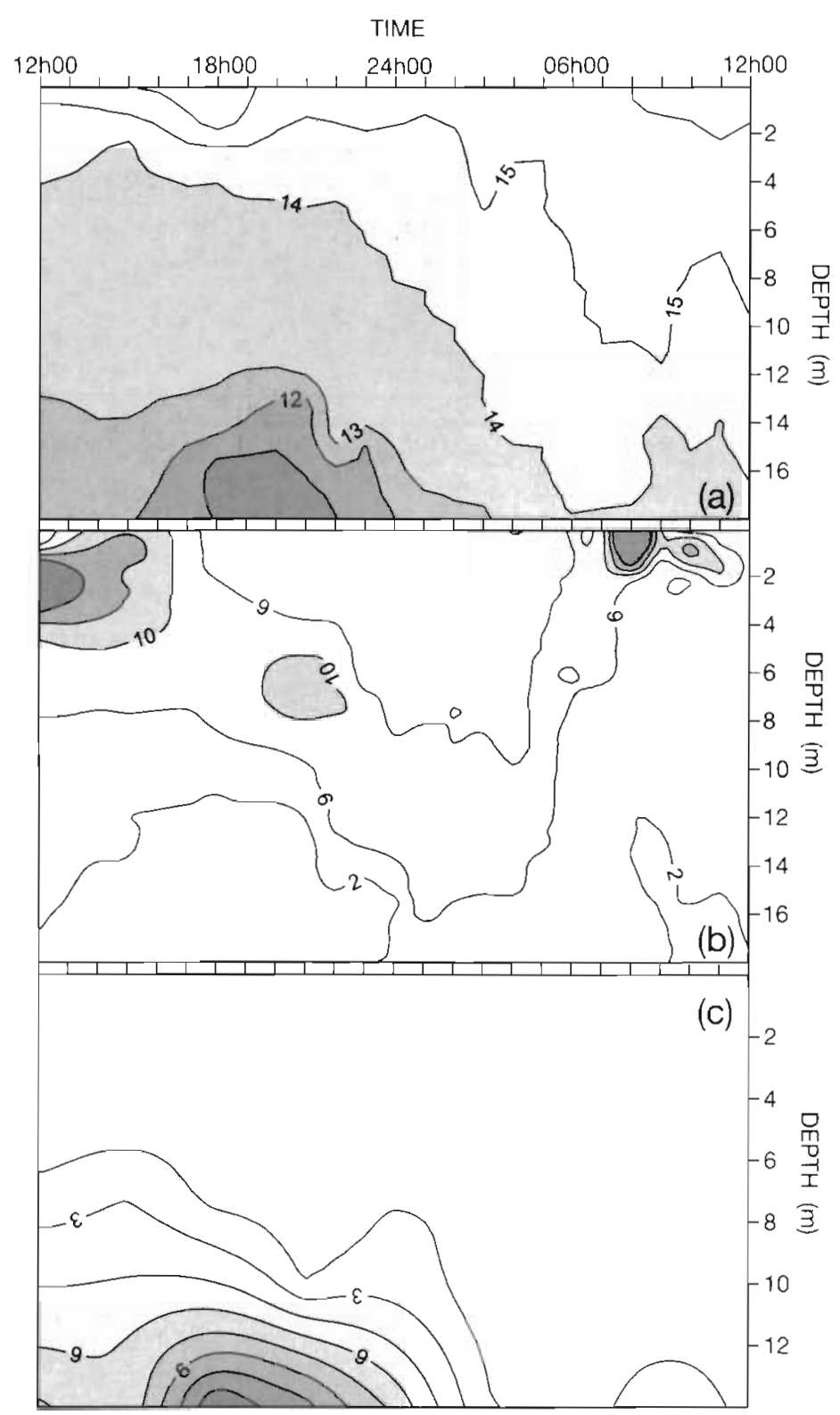

Fig. 8. Hourly monitoring of (a) temperature $\left({ }^{\circ} \mathrm{C}\right)$, (b) in situ fluorescence, and (c) nitrate concentrations $(\mu \mathrm{M})$ within a dinoflagellate bloom for the period 28 to 29 February 1996

\section{Coastal Transition Zone transect 1996}

The Coastal Transition Zone Front effectively forms the outer boundary to the productive West Coast waters. A transect of this front conducted on 6 February 1996 revealed the presence of 2 separate dinoflagellate populations, both of which were subsurface, between 20 and $40 \mathrm{~m}$ depth (Fig. 9). Offshore of the front a northbound remnant Agulhas Bank population was dominated by Prorocentrum rostratum, while Ceratium furca dominated the West Coast population inshore of the front. As in the case of the Lambert's Bay population, this assemblage included the toxic species Alexandrium catenella and Dinophysis acuminata.

From the Coastal Transition Zone Front and the Lambert's Bay transect studies it was evident that a spatially and temporally persistent subsurface dinoflagellate population dominated the stratified waters of the entire southern Benguela during the latter part of the upwelling season.

\section{Lambert's Bay 1997}

\section{Longshore advection}

A portion of the transect off Lambert's Bay was again sampled on $4 \mathrm{March} 1997$. In addition to sampling Stns 2 to 5, an ADCP was operated under way providing current data along the transect and down the water column in $2 \mathrm{~m}$ depth cells (Fig. 10). The thermal structure indicated a stratified environment with little acrossshelf variability. Red tide was evident in the inshore surface waters with the core of the bloom at $\operatorname{Stn} 3$. Stn 4 was situated outside of this surface bloom and at Stn 5 a subsurface bloom was manifest in a narrow band at $10 \mathrm{~m}$ depth. Several dinoflagellate species were common and again the toxic species Alexandrium catenella 
and Dinophysis acuminata were present. The $2 \mathrm{Cer}$ atium species, C. furca and C. lineatum, dominated the inshore surface bloom, together exceeding in certain instances a concentration of $6 \times 10^{6}{\text { cells } l^{-1}}^{-1}$

Current data at $6 \mathrm{~m}$ depth indicated that the inshore surface waters, characterized by red tide, were flowing southwards at approximately $15 \mathrm{~cm} \mathrm{~s}^{-1}$, while the surface waters offshore of the bloom were flowing at a similar velocity in a northerly direction. Current data at $28 \mathrm{~m}$ depth indicated southward flow along the entire transect. Temperature, in situ fluorescence and current profiles at Stn 5 indicate that the subsurface dinoflagellate population at $10 \mathrm{~m}$ depth was situated in the core of the northwesterly flow (Fig. 11). Current shear was conspicuous between 20 and $30 \mathrm{~m}$ depth, with southeasterly flow evident in the cold bottom waters. Thus despite little variation in the across-shelf thermal structure a strong colour front separated an inshore, southbound, surface dinoflagellate bloom from an offshore, northbound, subsurface population.
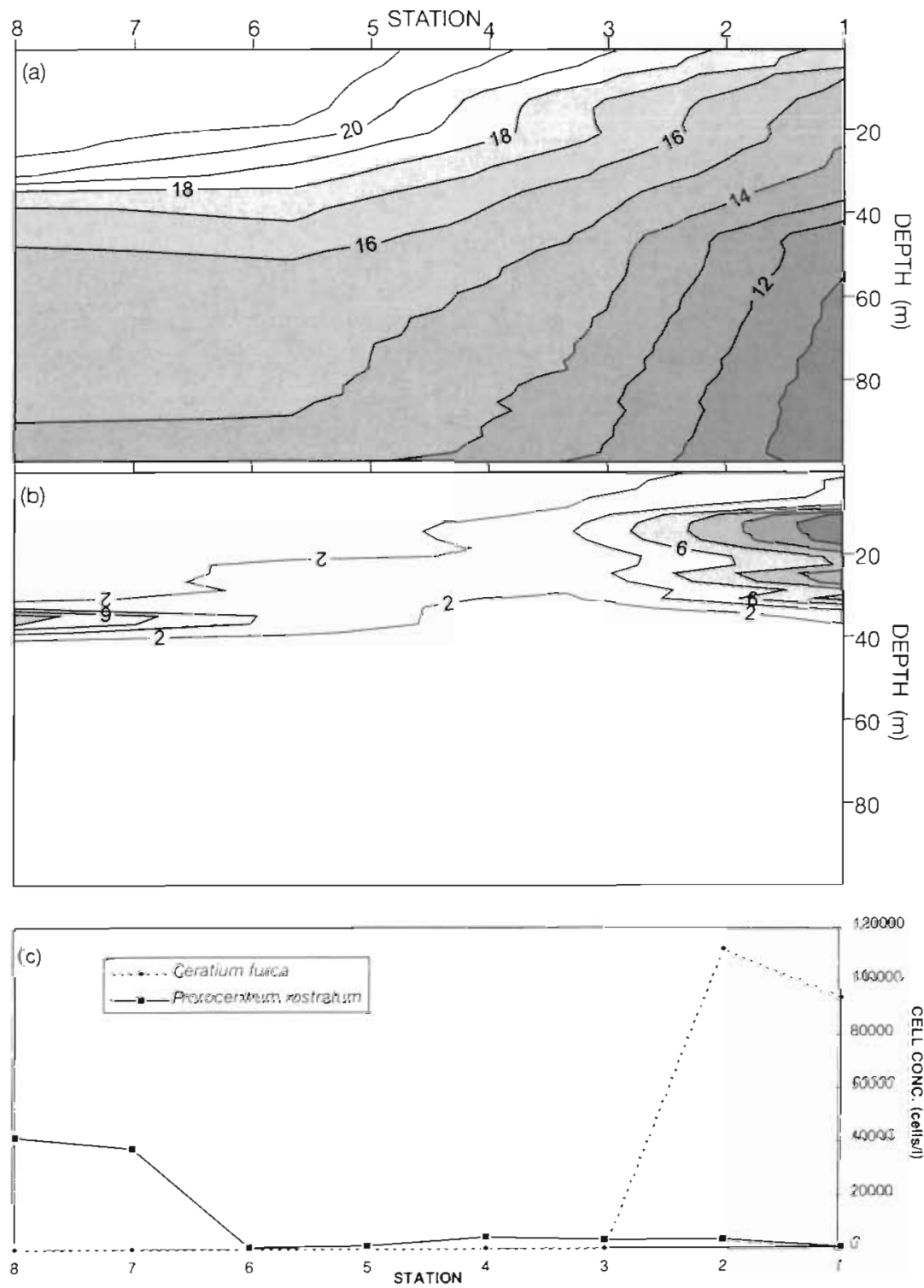

Fig. 9. A transect of the Coastal Transition Zone Front on 6 February 1996 of (a) temperature $\left({ }^{\circ} \mathrm{C}\right),(\mathrm{b})$ chlorophyll $\left(\mathrm{mg} \mathrm{m}^{-3}\right)$ and (c) the dinoflagellate species dominating the subsurface phytoplankton populations

\section{DISCUSSION}

The satellite thermal image of 6 February 1996 provides striking evidence of the complex patterns of sea surface temperature which prevail in the southern Benguela (Fig. 1). The consequent variability in the physical field which will impact the biological environment exhibits comparable alongshore and offshore scales. Colder regions indicate recently upwelled water, implying a high energy environment with delivery of nutrients to the euphotic zone through vigorous mixing Warmer regions on the other hand imply a lower energy environment and stratified water column. Here the requirements necessary for the growth of phytoplankton are segregated: at the surface light is abundant, but nutrients are low, whereas at depth nutrient concentrations are elevated but light is reduced. Of significance for this study is the observation that these different bodies of water are dominated by different life forms of phytoplankton, which reflect alternative strategies for survival in these different regimes of turbulence (Cullen \& Macintyre 1998).

Large areas of the southern Benguela become thermally stratified during the latter part of the upwelling seasorn as a result of increased solar irradiance. This is particularly the case off Lambert's Bay owing to a broadening of the shelf in this region. Inshore a narrow band of upwelling is responsible for a dynamic environment where advective responses to local meteorological forcing are responsible for rapid shifts in the biomass and species composition of the inshore phytoplankton community (Pitcher et al. 1996). 

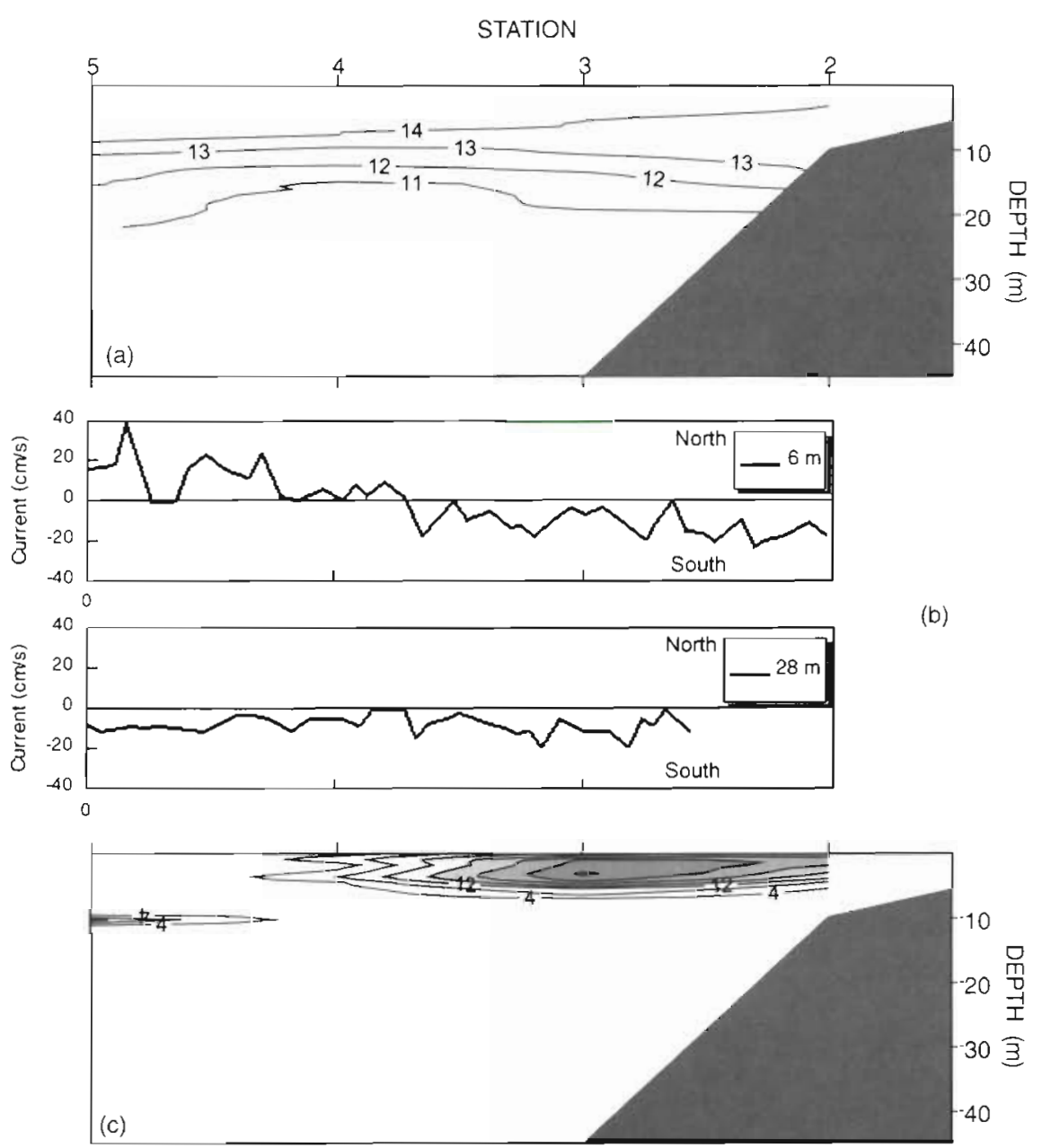

Fig. 10. A $10 \mathrm{n}$ mile transect off Lambert's Bay on 4 March 1997 of (a) temperature $\left({ }^{\circ} \mathrm{C}\right)$, (b) current components at 6 and $28 \mathrm{~m}$ depth and (c) in situ fluorescence

\section{Subsurface and frontal blooms}

Observations during this study indicate that spatial variations in the phytoplankton composition are determined by the vertical stability of the water column, which determines the availability of nutrients and light. Following upwelling high turbulence and nutrients favour the so-called mixers, notably the diatoms. The dinoflagellates, with their ability to regulate their depth, are typically associated with water columns of lower energy and lower nutrients. It appears, however, that a dichotomy exists in the dinoflagellate population: offshore the population tends to aggregate in a well-defined stratum in an attempt to balance light and nutrient requirements, while the frontal population is able to temporally separate nutrient uptake from photosynthesis by performing diel vertical migration, thereby demonstrating the ability of dinoflagellates to adapt their diel migratory behaviour to in situ conditions. (b)

Many cases of large, almost unialgal phytoplankton biomasses have been documented to occur during summer months in association with the pycnocline (Richardson 1997). The processes invoked to account for the formation and maintenance of such populations are diverse and include: subduction of surface populations, physical accumulation, enhanced growth in response to isopycnal nutrient fluxes, photoadaptation and reduced grazing stress (Franks \& Walstad 1997). The environment of layer formers is characterized by consistency in terms of light and nutrient supply, and accumulation at the pycnocline, where a minimal light requirement is met, will optimize the chances of being in that part of the water column where there is access to adequate nutrient and light supplies. It is nevertheless difficult to explain why phytoplankton sometimes appear to bloom under the low light conditions associated with the pycnocline, although Richardson et al. (1983) have argued that dinoflagellates in general have a relatively low light compensation point for growth (mean $6.6 \mu \mathrm{mol} \mathrm{m} \mathrm{m}^{-2}$ $\mathrm{s}^{-1}$ ). Quantification of the extent of these blooms and their importance in terms of the overall carbon fixation by phytoplankton is also difficult as this pycnocline layer is often very narrow and difficult to sample. In this respect the PNF has been very useful in this study, in establishing low photosynthetic activity in subsurface accumulations because of low in situ photon flux densities. A shallowing of the thermocline, as the front is approached from offshore, as a consequence of turbulent entrainment in the bottom boundary layer through tidal currents, will however improve the light environment of these subsurface populations. Furthermore, wind-induced vertical mixing and entrainment, diffusion, and internal wave activity are all processes that may periodically alter the light and nutrient environment and redistribute the dinoflagellate population. Alternately, the existence of large dinoflagellate cells in deep layers may intimate that processes such as phagotrophy, osmotrophy or at least resistance to grazing are important to their ecology (Cullen \& MacIntyre 1998).

The subsurface dinoflagellate population observed during this study is brought to the surface in the frontal 

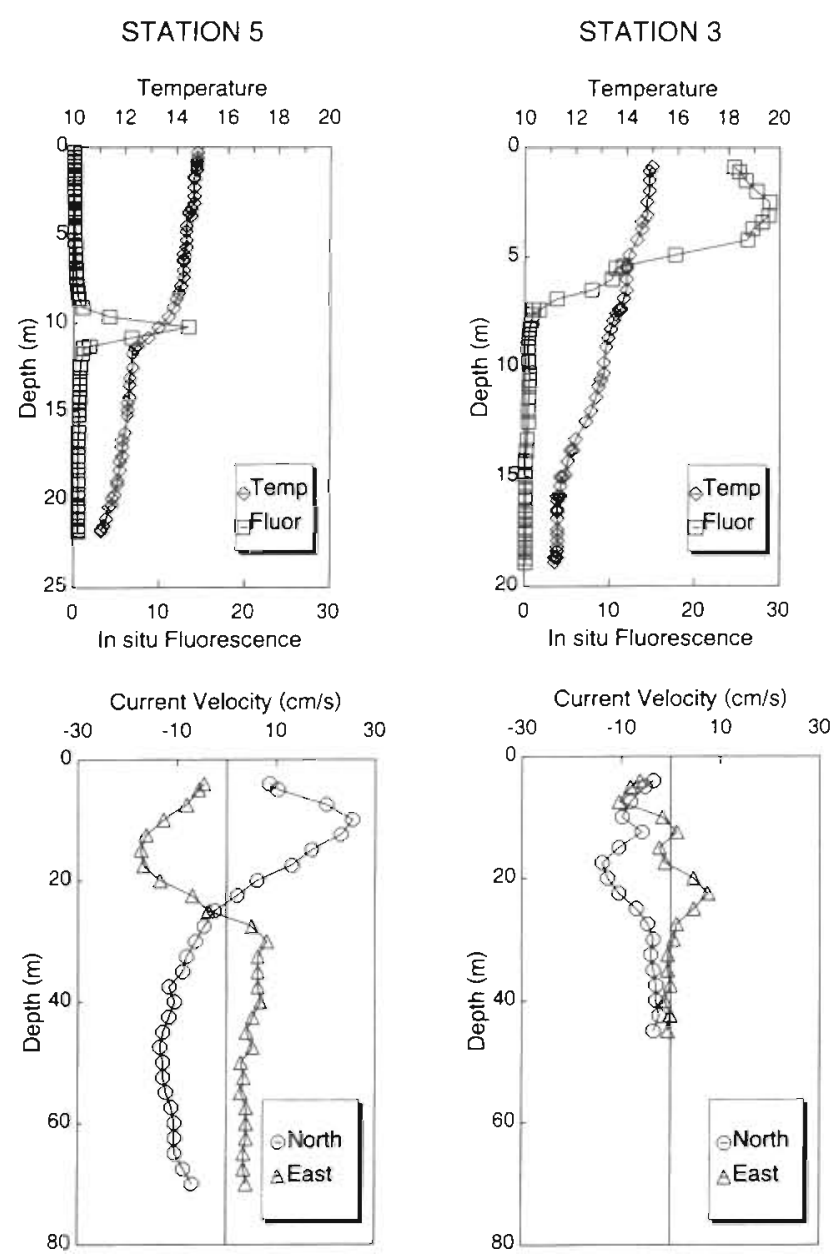

Fig. 11. Profiles of temperature $\left({ }^{\circ} \mathrm{C}\right)$, in situ fluorescence and currents at Stns 3 and 5 on 4 March 1997

region where isotherms intersect the surface and separate mixed inshore waters from stratified offshore waters. Here enhanced production owing to increased light levels results in dense dinoflagellate concentrations in and around the uplifted thermocline. Numerous studies have shown fronts to be the sites of enhanced biomass (Franks 1992) and the processes invoked to account for this enhanced production are diverse, and generally involve a physiological response of the organism to the physical dynamics of the front. Model predictions by Franks \& Walstad (1997) of phytoplankton biomass at fronts during transient wind events are supported by observations during this study. They predict that upwelling winds will erode subsurface patches, causing enhanced cross-frontal mixing leading to phytoplankton growth in the surface waters of the front, whereas downwelling winds will create enhanced vertical stratification, leading to isolation of subsurface populations and little cross-frontal transport.
Vertical migration, as observed during this study in inshore dinoflagellate populations, enables nutrients to be exploited over a relatively large part of the water column. The environment of migrators is characterized by extreme, but in large part predictable, variability in light and nutrients. Important adaptations for vertical migration are, therefore, necessary and include the capacity to take up nutrients in low light or in the dark, a photosynthetic physiology tuned to exploiting varying irradiance, and appropriate behavioural responses that are regulated by environmental feedback (Cullen \& Macintyre 1998). Examination during this study of the vertical distribution of individual dinoflagellate species during a $24 \mathrm{~h}$ period revealed various patterns of migration, thereby segregating species in the water column, with each species occupying a different niche within the vertical gradients of light and nutrients (Horstman \& Pitcher unpubl.). For these motile phytoplankton, vertical movements, though phased to solar irradiance, are governed by many factors besides phototaxis (Kamykowski 1995). Patterns of migration differ between species because responses to these factors partially define the niche of migratory phytoplankton. Here they are seen to differ in the level of aggregation during the day and the extent of nocturnal descent. Each species thus has a unique suite of nutrient- and light-dependent verticall migration patterns, each suited to a particular hydrographic regime (Cullen 1985). The challenge is to infer from field observations and experimental results which conditions will cause a particular species to bloom, or cause its strategy to fail (Cullen \& MacIntyre 1998).

\section{A conceptual model of red tide}

Observations made during this study permit development of a conceptual model of the formation of red tide within the upwelling system of the southern Benguela. Dinoflagellates increase relative to diatoms as seasonal stratification increases during the course of the upwelling season. Outside centres of upwelling, a broadening of the shelf is responsible for intensified stratification, thereby favouring a widespread distribution of dinoflagellates across the entire shelf. Here the population develops subsurface in association with the thermocline. The inshore region is subjected to a narrow coastal strip of upwelling and the dinoflagellate population appears as a surface bloom in the region of the upwelling front which is displaced from the coast during the active phase of upwelling. Red tide forms and impacts on the coast following relaxation of upwelling. As wind stress decreases during the quiescent phase of upwelling, cross-shelf currents become weaker and directed onshore. The return of warm 
near-surface water corresponds to the onshore movement of the upwelling front and will often be accompanied by mean southward currents. Under these conditions the dinoflagellate population is accumulated inshore, where net poleward surface flow is responsible for the southward propagation of red tide.

The close proximity of cold bottom water to the surface on the inner shelf of the West Coast makes the inshore environment particularly responsive to local meteorological forcing, which in turn makes acrossshelf and longshore movement of the bloom predictable. Current data collected in this region (G. Nelson, Sea Fisheries Research Institute, unpubl, data) indicate that onshore and alongshore current speeds typically range between 8 and $12 \mathrm{~cm} \mathrm{~s}^{-1}$. This information may be used in modelling the dynamics of the upwelling front, which will allow prediction of the timing, location, magnitude and duration of these coastal accumulations of frontal blooms.

A number of dinoflagellates have been reported to form pycnocline and surface blooms in association with offshore frontal regions. For example, accumulations of Gyrodinium aureolum at shelf sea fronts are particularly well documented, and coastal blooms of $G$. aureolum may result from the onshore advection of these offshore populations (Richardson 1997). Similar frontal accumulations and onshore delivery mechanisms have been proposed in other marine ecosystems (Anderson 1997), and observations during this study have established the importance of these same mechanisms in the dynamics of dinoflagellate blooms of the southern Benguela upwelling system.

Acknowledgements. We are grateful to Drs C. Duncombe Rae and L. Hutchings for the provision of data and samples collected on the transect of the Coastal Transition Zone Front and to Mrs D. Calder for analysing and counting numerous phytoplankton samples.

\section{LITERATURE CITED}

Anderson DM (1997) Bloom dynamics of toxic Alexandrium species in the northeastern U.S. Limnol Oceanogr 42: $1009-1022$

Brown PC, Hutchings L, Horstman DA (1979) A red-water outbreak and associated fish mortality at Gordon's Bay near Cape Town. Fish Bull S A.fr 11:46-52

Chamberlin WS, Booth CR, Kiefer DA, Morrow JH, Murphy RC (1990) Evidence for a simple relationship between natural fluorescence, photosynthesis and chlorophyll in the sea. Deep-Sea Res 37:951-973

Cullen JJ (1985) Diel vertical migrations by dinoflagellates: roles of carbohydrate metabolism and behavioural flexibility. Contrib Mar Sci 27(Suppl):135-152

Cullen JJ, Lewis MIR (1995) Biological processes and optical measurements near the sea surface: some issues relevant to remote sensing. J Geophys Res 100:13255-13266
Cullen JJ, MacIntyre JG (1998) Behaviour, physiology and the niche of depth-regulating phytoplankton. In: Anderson DM, Cembella AD, Hallegraeff GM (eds) The physiological ecology of harmful algal blooms. NATO A.SI Series, Springer-Verlag, Heidelberg, p 559-580

Franks PJS (1992) Sink or swim: accumulation of biomass at fronts. Mar Ecol Prog Ser 82:1-12

Franks PJS, Walstad LJ (1997) Phytoplankton patches at fronts: a model of formation and response to wind events. $J$ Mar Res 55:1-29

Grindley JR, Nel E (1968) Mussel poisoning and shellfish mortality on the West Coast of South Africa. S Afr J Sci 64: $420-422$

Grindley JR, Sapeika N (1969) The cause of mussel poisoning in South Africa. S Afr Med J 43:275-279

Grindley JR, Taylor FJR (1964) Red water and marine fauna mortality near Cape Town. Trans R Soc S Afr 37:111-130

Hasle GR (1978) The inverted-microscope method. In: Sournia A (ed) Phytoplankton manual. UNESCO, Paris, $\mathrm{p}$ $88-96$

Horstman DA (1981) Reported red-water outbreaks and their effects on fauna of the West and South Coasts of South Africa, 1959-1980. Fish Bull S Afr 15:71-88

Horstman DA, MCGibbon S, Pitcher GC, Calder D, Hutchings L, Williams P (1991) Red tides in False Bay, 1959-1989, with particular reference to recent blooms of Gymnodinium sp. Trans R Soc S Afr 47:611-628

Kamykowski $D$ (1995) Trajectories of autotrophic marine dinoflagellates. J Phycol 31:200-208

Matthews SC, Pitcher GC (1996) Worst recorded marine mortality on the South African coast. In: Yasumoto $T$, Oshima Y. Fukuyo Y (eds) Harmful and toxic algal blooms. Intergovernmental Oceanographic Commission of UNESCO, Paris, p 89-92

Mostert SA (1983) Procedures used in South Africa for the automatic photometric determination of micronutrients in seawater. S Afr J Mar Sci 1:189-198

Nelson G, Hutchings L (1983) The Benguela upwelling area Prog Oceanogr 12:333-356

Parsons TR, Maita Y, Lalli CM (1984) A manual of chemical and biological methods for seawater analysis. Pergamon Press, New York

Pitcher GC, Boyd AJ (1996) Across-shelf and alongshore dinoflagellate distributions and the mechanisms of red tide formation within the southern Benguela upwelling system. In: Yasumoto T, Oshima Y, Fukuyo Y (eds) Harmful and toxic algal blooms. Intergovernmental Oceanographic Commission of UNESCO, Paris, p 243-246

Pitcher G, Matthews S (1996) Noxious Gymnodinium species in South African waters. In: Wyatt $\mathrm{T}$ (ed) Harmful algae news. Intergovernmental Oceanographic Commission of UNESCO, Paris, No. 15, p 1-3

Pitcher GC, Horstman DA, Calder D (1993a) Formation and decay of red tide blooms in the southern Benguela upwelling system during the summer of 1990/91 In: Smayda TJ, Shimizu Y (eds) Toxic phytoplankton blooms in the sea. Elsevier Science Publishers, New York, p 317-322

Pitcher GC, Horstman DA, Calder D, de Bruyn JH, Post BJ (1993b) The first record of diarrhetic shellfish poisoning on the South African coast. S Afr J Sci 89:512-514

Pitcher G, Agenbag J, Calder D, Horstman D, Jury $M$, Taunton-Clark J (1995) Red tides in relation to the meteorology of the southern Benguela system. In: Lassus $\mathrm{P}$, Arzul G, Erard E, Gentien P, Marcaillou C (eds) Harmful marine algal blooms. Technique et Documentation, Lavoisier, Intercept Ltd, Paris, p 657-662 
Pitcher GC, Richardson AJ, Korrubel JL (1996) The use of sea temperature in characterizing the mesoscale heterogeneity of phytoplankton in an embayment of the southern Benguela upwelling system. J Plankton Res 18: 643-657 Popkiss MEE, Horstman DA, Harpur D (1979) Paralytic shellfish poisoning: a report of 17 cases in Cape Town. S Afr Med J 55:1017-1023

Richardson K (1997) Harmful or exceptional phytoplankton blooms in the marine ecosystem. Adv Mar Biol 31:302-385

Editorial responsibility: Otto Kinne (Editor), Oldendorf/Luhe, Germany
Richardson K, Beardall J, Raven JA (1983) Adaptation of unicellular algae to irradiance: an analysis of strategies. New Phytol 93:157-191

Shannon LV (1985) The Benguela ecosystem Part I. Evolution of the Benguela, physical features and processes. Oceanogr Mar Biol Annu Rev 23:105-182

Smayda TJ (1978) From phytoplankters to biomass. In: Sournia A (ed) Phytoplankton manual. UNESCO, Paris, $p$ $273-279$

Submitted: February 16, 1998; Accepted: July 2, 1998 Proofs received from author(s): September 22, 1998 